\title{
MANAGEMENT OF ACNE VULGARIS BY PRINCIPLES OF AYURVEDA: A CASE STUDY
}

Pradip Kinage ${ }^{1 *}$, Deepika Chaudhari ${ }^{2}$

${ }^{1}$ Assistant Professor, Department of Prasuti Tantra \& Striroga, Mahatma Gandhi Ayurveda College Hospital and

Research centre, Salod (H), Maharashtra, India

${ }^{2}$ Asstistant Professor, Department of Sharir Kriya, R D Memorial PG College of Ayurveda, Bhopal, Madhya Pradesh, India

Received on: 07/03/16 Revised on: 02/04/16 Accepted on: 19/04/16

* Corresponding author

E-mail: kinagepradeep@gmail.com

DOI: $10.7897 / 2277-4343.07284$

\begin{abstract}
Acne is one of the most troublesome, frustrating and common skin-care problems for people around the world. Acne vulgaris is the most common disorder treated by dermatologists. Acne is a disease of pilosebaceous units characterized by the formation of the open and closed comedones, papules, pustules, nodules and cysts. This condition can be correlated with Mukhadushika. The incidence of Mukhadushika is increasing day by day due to consumption of junk food, fast food and cold drinks etc. which leads to imbalances in Doshas. This case is an ideal example of Mukhadushika and is successfully managed with Ayurveda therapy. Patient was suffering from acne on face, blackish spots, itching \& burning sensation over facial skin along with pain since last one and half year. Considering clinical features and Kapha, Vata, Rakta involved in pathology; patient was treated with oral administration of Gandhak Rasayan and Triphala Churna along with external application (Lepa) of powder of Manjishtha, Lodhra, Haridra, Nimbapatra on face. After 15 days Ushir powder was added in Lepa instead of Nimbapatra; considering poor response to burning sensation. Treatment was continued for next 15 days. At the end of treatment, there was complete disappearance of acne, relief in itching, burning sensation and pain. Significant improvement was also observed in discoloration over face. Hence it was concluded that Lepa of Manjishtha, Lodhra, Nimbapatra, Haridra and Ushir Churna along with oral administration of Gandhak Rasayan and Triphala Churna is highly effective in the management of Mukhadushika.
\end{abstract}

Keywords: Acne, Mukhadushika, Manjishtha, Lodhra, Ushir, Gandhak Rasayan.

\section{INTRODUCTION}

Every person wants to look beautiful. Even a small spot on the face especially of younger one causes worry. A clear complexion might have created a stronger self image and a higher sense of self confidence. Unfortunately, acne hits young people at a time when they most want to look their best. Acne is a disease of sebaceous gland which occurs only during particular age period. The condition usually starts in adolescence and resolves by the mid-twenties, but in some patients it may persists up to the age of 35 years and more. Patients having acne have an associated increased secretion of the sebaceous gland leading to increased oiliness of the skin. This is acted upon by the normal flora of the skin. Fatty acids along with the other components of the sebaceous secretions and the bacteria are responsible for producing the acne lesions. The lesion consists of open comedones (black heads), close comedones (white heads), inflammatory papules, papulo-pustules and cystic lesions; frequently on the cheeks but also involve forehead, nose, chin and occasionally on the back and chest. ${ }^{1-2}$ In Ayurveda science, this condition can be correlated with Mukhadushika. Yuvanpidaka, Mukhadushika and Tarunyapidaka are synonyms mentioned in Ayurvedic texts. In Sushrut Samhita, Mukhadushika is mentioned under Kshudra Rogas (Minor diseases). Mukhadushika (Acne vulgaris) by the name also it clears that it is a disease affecting face and Yuvanpidaka or Tarunyapidaka explain its onset during the period of young age. ${ }^{3}$ Adolescence and girls around twenties are having more concern about their good look. Acne suppresses an individual's self confidence by causing distress with regard to physical appearance; which affects a significant number of individuals during Yuvan (Young age). Acne vulgaris is found to have similarity with the disease Mukhadushika. These are Shalmali thorn like eruptions on the face due to vitiation of Kapha, Vata and Rakta which are found on the face. ${ }^{4-5}$ Allopathic management of acne includes topical application of antibacterial, antiseptic creams, use of calamine lotion etc. Systemic antibiotics are used if acne is not treated by topical application. ${ }^{6}$ Patient has tried out all these measures but had no relief. So she was given Ayurveda management in the form of Gandhak Rasayan, Triphala Churna orally and Manjishtha, Lodhra, Nimbapatra, Haridra, Ushir Churna for lepa (external application) over face. Patient was successfully managed with this treatment without any side effects.

\section{MATERIALS AND METHODS}

Place of study- Mahatma Gandhi Ayurveda College Hospital and Research centre, Salod $(\mathrm{H})$, Wardha, Maharashtra, India, 442001.

Case Report- The present case study is successful Ayurvedic management of a case of Mukhadushika (Acne vulgaris). A 20year-old female patient with Registration no 1601150005 came to Mahatma Gandhi Ayurveda College Hospital and Research centre, Salod (H), Maharashtra, India, with chief complaints of 1. Acne on face (Pidaka)

2. Pain over face (Vedana)

3. Itching over face (Kandu)

4. Burning sensation (Daha)

5. Discoloration of face (Vaivarnya)

Associated symptom was- mild constipation. 
Patient had above complaints since one and half year.

\section{History of present illness}

The patient was normal one and half year back. But Since then patient has been suffering from acne on face, blackish spots, itching \& burning sensation over facial skin along with pain. Patient was also psychologically upset since last 6 months. She had used various local and oral allopathic medicines. But there was no any significant relief. Even local use of soaps and creams were worsening the acne. Hence she came to Mahatma Gandhi Ayurveda College and Hospital, Salod (H), Maharashtra, India, for management.

Past History: Not significant.

\section{Personal History:}

Table 1: Personal history

\begin{tabular}{|c|c|c|}
\hline Name: xyz & Bala: Madhyama (Average) & Prakriti: Pitta Vata \\
\hline Age:20years & Sleep: Inadequate & BP:110/70 $\mathrm{mmHg}$ \\
\hline Sex: Female & Addiction: None & Weight: $40 \mathrm{~kg}$ \\
\hline Marital status: Unmarried & Bowel habit: Irregular & Height: $158 \mathrm{~cm}$ \\
\hline Occupation: Student & Appetite: Poor & \\
\hline
\end{tabular}

\section{Ashtavidha Pariksha}

Table 2: Ashtavidha Pariksha

\begin{tabular}{|ll|ll|}
\hline Nadi (pulse): & $80 /$ min & Shabda (speech): & Clear \\
\hline Mala (stool): & Constipation & Sparsha (touch): & Normal \\
\hline Mutra (urine): & Normal & Druka (eyes): & Normal \\
\hline Jivha (tounge): & Saam (Coated) & Akruti (built): & Madhyama \\
\hline
\end{tabular}

Treatment plan- Patient was treated on OPD basis.

A) Selected Internal Ayurvedic Drugs:

Gandhak Rasayan and Triphala Churna were selected for oral administration.

Table 3: Dose, Route, Kala (drug administration time) and Anupan (vehicle) of drugs used in the management

\begin{tabular}{|c|c|c|c|c|}
\hline Name Of Medicine & Dose & Route & Kal & Anupan \\
\hline Gandhak Rasayan & $250 \mathrm{mg}$ three times/day & Oral & Adhobhakta (after meal) & Water \\
\hline Triphala Churna & 3 grams once/day & Oral & Nishikal (bed time) & Koshna Jala (luke warm water) \\
\hline
\end{tabular}

Duration: 15 Days

Criteria for Selection of internal medicines: Oral medications were selected on the basis of their properties useful in pacifying vitiated Dosha in Mukhadushika and ability to relieve signs and symptoms of Mukhadushika.

Table 4: Ingredients of preparation used for oral administration with their use $\mathrm{e}^{7-8}$

\begin{tabular}{|l|l|l|}
\hline Name Of Medicine & \multicolumn{1}{|c|}{ Ingredients } & \multicolumn{1}{c|}{ Properties and use } \\
\hline Gandhak Rasayan & $\begin{array}{l}\text { Guda, Ghee, Shunthi, Pippali, Twak, Ela. Marich, Vidang, } \\
\text { Patra, Triphala, Rasna, Bhringaraj, Bakuchi, Erandabeej, } \\
\text { Gandhak, Lohabhasma, Madhu }\end{array}$ & $\begin{array}{l}\text { Raktashodhak, Vranropak, Twachya, useful in skin } \\
\text { disease. }\end{array}$ \\
\hline Triphala Churna & Amalaki, Haritaki, Bibhitaki & $\begin{array}{l}\text { Tridoshghna, Mridu Virechak (mild purgative). } \\
\text { Kushthghna, Deepaniya (Improve appetite). }\end{array}$ \\
\hline
\end{tabular}

\section{B) Selected external Ayurvedic Drugs}

Drug: Powder of Manjistha (2gms), Lodhra (2gms), Nimbapatra (2gms), Haridra (1gms) with water in the form of paste.

Dose: Application on face once a day.

The mixture was advised to apply on the face once daily; left for 20 minutes and rinsed off using cold water.
Duration: Treatment was carried out daily for 15 days.

Follow up: After 15 days.

Criteria for Selection of external medicines: Medicines for external application were selected due to their properties beneficial for treating acne vulgaris. 
Table 5: Ingredients of Lepa with their properties ${ }^{9-14}$

\begin{tabular}{|l|l|l|l|}
\hline Name of ingredients & Latin name & Dose & Properties \\
\hline Manjishtha & Rubia cordifolia & $2 \mathrm{gm}$ & $\begin{array}{l}\text { Varnya (Beneficial for skin colour), Kapha-Pitta Shamak, Shothahar (Reduce } \\
\text { swelling), Kushthaghna (Beneficial for skin diseases), Vranropak (Wound } \\
\text { healing), Raktashodhak (Blood purifier). }\end{array}$ \\
\hline Lodhra & Symplocos recemosa & $2 \mathrm{gm}$ & $\begin{array}{l}\text { Kashay (Astringent), Shit (cold), Kapha-Pitta Shamak, Shothahar, Kushthaghna, } \\
\text { Vranropak. }\end{array}$ \\
\hline Nimbapatra & Azadirachta indica & $2 \mathrm{gm}$ & Kapha-Pitta Shamak, Raktadoshahar, Kushthaghna, Vranropak. \\
\hline Haridra & Curcuma longa & $1 \mathrm{gm}$ & $\begin{array}{l}\text { Tridoshshamak, Shothahar, Kushthaghna, Vranropak, Vranshodhak, Varnya, } \\
\text { Vedanasthapak (Reduce pain), Kandughna (Reduce itching). }\end{array}$ \\
\hline $\begin{array}{l}\text { Ushir } \\
\text { (Used after 1st follow up) }\end{array}$ & Vetiveria zizanioidis & $2 \mathrm{gm}$ & $\begin{array}{l}\text { Varnya, Dahaprashaman (Reduce burning), Kapha-Pitta Shamak, Twakdoshahar } \\
\text { (Beneficial for skin problems), Kushthaghna, Raktaprasadan. }\end{array}$ \\
\hline
\end{tabular}

Preparation of Lepa: Patient was asked to take $2 \mathrm{gms}$ of Manjishtha and Lodhra Churna each. Then it was added with 1 gm of Haridra Churna and 2 grams of Nimbapatra Churna. Adequate water was added to mix them. Lepa was prepared fresh every day.

All the internal and external medicines used in this case were prepared in Dattatreya Rasashala of Mahatma Gandhi Ayurveda College Hospital and Research centre, Salod $(\mathrm{H})$, Wardha, Maharashtra, India, which is FDA approved, so as to assure authenticity of drugs.

Ahar and Vihar (Diet and mode of life) advised during treatment:

Pathya (Regimen to be follow): Green gram, rice, wheat, green vegetables, fruits.

Adequate sleep at night (8hours)

Washing face every time coming from external environment and sleeping at night.
Apathya (Regimen to be restricted): Ice cream, cold drinks, curd, bread, toast, oily substances like chips etc, non-veg, egg, fast food, tea and coffee.

Night awaking (Ratri Jagran), Daytime sleeping (Divaswap), squeezing of acne, excessive exposure to sunlight.

Counseling- As patient was also psychologically upset hence proper counseling of patient was done. She was made aware about hormonal changes in female body around this age. Patient was made confident that this condition is treatable.

Follow up $1^{\text {st }}$ - After first follow up, Nimba Patra was replaced with equal amount of Ushir Churna (2gms), while rest of the contents was same. There were no changes in the internal management.

Duration- This treatment was carried out for 15 days.

Follow up $2^{\text {nd }}$ - After 15 days.

Signs and symptoms of the patient regarding acne were assessed during each follow up and results were drawn after last follow up.

\section{Grading}

Table 6: Criteria for assessment of results

\begin{tabular}{|c|c|c|c|c|}
\hline Sign and symptoms & Normal 0 & Mild (1) & Moderate (2) & Severe (3) \\
\hline Acne(in number) & No acne (0) & $1-3(1)$ & $4-9(2)$ & More than 9 (3) \\
\hline Burning & 0 & 1 & 2 & 3 \\
\hline Itching & 0 & 1 & 2 & 3 \\
\hline Pain & 0 & 1 & 2 & 3 \\
\hline Discoloration & 0 & 1 & 2 & 3 \\
\hline
\end{tabular}

\section{OBSERVATION AND RESULTS}

Assessment of signs and symptoms of the patient regarding acne was done during each follow up and results were as follows-

Assessment of signs and symptoms of acne vulgaris (Mukhadushika) before and after treatment are as-

Table 7: Changes in signs and symptoms during each follow up

\begin{tabular}{|c|c|c|c|}
\hline Sign and Symptoms & before treatment & $\mathbf{1}^{\text {st }}$ follow up & $\mathbf{2}^{\text {nd }}$ follow up \\
\hline Acne & 3 & 1 & 0 \\
\hline Burning & 3 & 3 & 0 \\
\hline Itching & 2 & 1 & 0 \\
\hline Pain & 1 & 0 & 0 \\
\hline Discoloration & 3 & 2 & 1 \\
\hline
\end{tabular}

Table 7 shows that there is significant relief in all signs and symptoms of Mukhadushika. It means selected management of Mukhadushika is effective. 


\section{DISCUSSION}

In Ayurvedic Samhitas Mukhadushika is described very shortly. In Ashtang Sangraha it is mentioned that these Pidaka looks like thorn of Shalmali tree. Acharya Sushruta has pointed out vitiated Kapha, Vata, Rakta as the causative factors of the disease. Acharya Vagbhat has also mentioned Medodushti in Mukhadushika. According to modern, it is a disease of sebaceous gland causing macules, papules, black spots etc. on face. Topical applications of antibacterial, antiseptic creams, calamine lotion etc. is commonly prescribed by modern science. Systemic antibiotics are prescribed if acne is not treated by topical application. According to modern acne patient doesn't need to observe any dietary precautions. This patient has tried out all these allopathic measures but had no relief. But Ayurveda has different holistic view while treating any disease. Diets, mode of life, psychological status are considered as important, along with medicinal management. This case was ideal case of Mukhdushika. Patient was taking fast food; oily, salty substances; bakery products regularly. She was having habit of Adhyashan (Eating even after taking full diet). Patient was also practicing Ratri Jagaran (night awaking) and Divaswap (Daytime sleeping). These etiological factors may be the cause for vitiation of Tridosha along with Rakta and resulted in formation of Pidaka (Acne) on face with clinical features like burning sensation, pain, discolouration, itching etc. Both internal and external treatments were selected for this patient considering Ayurveda Principles. Gandhak Rasayan is used in skin diseases and as a blood purifier, hence selected for study. Triphala Churna is also found beneficial in acne and it is also relieving constipation, hence selected along with Gandhak Rasayan for oral administration. Manjishtha, Lodhra, Haridra and Nimbapatra were used for external application. All these drugs are having properties like Varnya (Good for skin colour), Kapha-Pitta Shamak, Shothahar (Reduce swelling), Kushthaghna (Beneficial in skin disease), Vranropak (Wound healing), Raktashodhak (Blood purifier), Vedanasthapak (Reduce pain), Kandughna (Reduce itching) and Dahaprashaman (Reduce burning), which are helpful in treating acne. This remedy was given for 15 days. During complete duration of treatment, patient was instructed to follow Pathya (do's) and Apathya (don'ts) as advised strictly. During first follow up it was found that there is significant relief in all signs and symptoms of acne except burning sensation. Ushir is highly effective in burning sensation. Hence Ushir Churna was added in Lepa instead of Nimbapatra for next 15 days. Patient was examined again after 15 days. There was disappearance of acne, complete relief in itching, burning sensation and pain. Significant improvement was observed in discoloration over face from grade 3 to grade 1 . This shows that if plan of treatment is selected according to Principles of Ayurveda along with proper drugs, doses, duration, Anupan, Pathya and Apathya there is assurance of success in treatment as seen in this case of Mukhadushika.

\section{CONCLUSION}

Hence it is concluded that Lepa of Manjishtha, Lodhra, Nimbapatra, Haridra and Ushir Churna along with oral administration of Gandhak Rasayan, Triphala Churna is highly effective in the management of Mukhadushika (Acne vulgaris).

\section{REFERENCES}

1. Walker B R, Colledge N R et.al, Davidson's principles and practice of medicine, $20^{\text {th }}$ edition, Chapter no 27, Elsevier publication, China, p. 1267-1269.

2. Goyal DK, Bhawana Sahrma, Pawan Garg, Case study of Acne Vulgaris (Youvan Pidika): Case Report, International Journal of Ayurvedic Medicine, 2015, 6(4), 337-341.

3. Joshi Y G, Text book of Kayachikitsa, Chapter no 18, Shri Ganesh publisher, Pune, 2010. p.198-199.

4. Dwivedi Laxmidhar, Sushruta samhita, vol 2, Chaukhamba sanskrit series, Varanasi 2002, nidan sthan, chapter no 13, verse no 38, p. 104.

5. Rao Shrinivas P, Ashtang Sangraha, vol 3, Choukhamba krishhndas academy, Varanasi 2009, uttar sthan, chapter 36, verse no 7, p. 323

6. Pasricha J S, Gupta Rammji, Illustrated textbook of dermatology, $3^{\text {rd }}$ edition, Chapter no 18, Jaypee publications, 2006, p. 126-129.

7. Joshi Y G. Textbook of Kayachikitsa, Chapter no 79, shri ganesh publisher, Pune, 2010, p. 651.

8. Sharma Priyavat, Dravyagun vidnyan, vol -1 , Dravya khanda, chapter no 6, Chaukhamba bharati prakashan, Varanasi 2014, p. 70.

9. Sharma Priyavat, Dravyagun vidnyan vol -2 , Chapter no 9, Chaukhamba bharati prakashan, Varanasi, 2014, p .800-802.

10. Sharma Priyavat, Dravyagun vidnyan, vol -2 , Chapter no 7 , Chaukhamba bharati prakashan, Varanasi, 2014, p. 616-617.

11. Sharma Priyavat, Dravyagun vidnyan, vol -3, Chapter no 3, Chaukhamba bharati prakashan, Varanasi, 2014, p. 201.

12. Sharma Priyavat, Dravyagun vidnyan, vol -2 , Chapter no 2 , Chaukhamba bharati prakashan, Varanasi 2014, p.162-165.

13. Sharma Priyavat, Dravyagun vidnyan, vol -2 , Chapter no 2 , Chaukhamba bharati prakashan, Varanasi, 2014,p.114-116.

14. Radha Gupta, Sharad Porte, Manjishtha (Rubia Cordifolia Linn.) An Ayurvedic Drug: Literary Review, Int. J. Res. Ayurveda Pharma. 2015; 6(1):90-97.DOI: 10.7897/22774343.0612 .

\section{Cite this article as:}

Pradip Kinage, Deepika Chaudhari. Management of acne vulgaris by principles of Ayurveda: A case study. Int. J. Res. Ayurveda Pharm. Mar - Apr 2016;7(Suppl 2):188-191 http://dx.doi.org/10.7897/2277-4343.07284

Disclaimer: IJRAP is solely owned by Moksha Publishing House - A non-profit publishing house, dedicated to publish quality research, while every effort has been taken to verify the accuracy of the content published in our Journal. IJRAP cannot accept any responsibility or liability for the site content and articles published. The views expressed in articles by our contributing authors are not necessarily those of IJRAP editor or editorial board members. 